\title{
Geomorphological Evolution and Fluvial System Development during the Holocene: The Case of Vouraikos River Evolution in Kalavrita Plain, Northern Peloponnese, Greece
}

\author{
Leonidas Stamatopoulos ${ }^{1 *}$, Georgios Alevizos ${ }^{1 *}$, Niki Evelpidou ${ }^{2}$ \\ ${ }^{1}$ Department of Geology, University of Patras, Patras, Greece \\ ${ }^{2}$ Department of Geography-Climatology, Faculty of Geology and Geoenvironment, \\ National \& Kapodistrian University of Athens, Athens, Greece \\ Email: *leonstan@upatras.gr, *george_alevizos@hotmail.com
}

How to cite this paper: Stamatopoulos, L., Alevizos, G. and Evelpidou, N. (2018) Geomorphological Evolution and Fluvial System Development during the Holocene: The Case of Vouraikos River Evolution in Kalavrita Plain, Northern Peloponnese, Greece. Journal of Geoscience and Environment Protection, 6, 17-35.

https://doi.org/10.4236/gep.2018.61002

Received: October 28, 2017

Accepted: January 13, 2018

Published: January 16, 2018

Copyright $\odot 2018$ by authors and Scientific Research Publishing Inc. This work is licensed under the Creative Commons Attribution International License (CC BY 4.0).

http://creativecommons.org/licenses/by/4.0/

(c) (i) Open Access

\begin{abstract}
Fluvial geomorphology is affected by physical conditions which allow its adaptation due to high dynamics and environmental influences. Fluvial morphological changes are manifested as a result of tendency of the river system to maintain its physical balance. Our study area is the upper and middle flow part of Vouraikos river and surrounding area, near the NW border of Chelmos mountain in Northern Peloponnese, near the town of Kalavrita, at an altitude of 800 $\mathrm{m}$. The area is part of the Skepasto basin, constituting of a graben with a general E-W direction that was developed NW of Kalavrita. The area comprises of Mesozoic, Upper Triassic-Jurassic limestone and dolomite of the Tripolitsa unit External Hellenides and Plio-Pleistocene fluvio-lacustrine sequences, while its tectonic structure is characterized mainly by normal faults. The geomorphological landscape is characterized by alluvial deposits and important geomorphological features including fluvial terraces, alluvial fans, fluvial scarps and their main rill washes. This area has been a place of major human activity as shown by the findings of many uncovered artifacts and a settlement. Through a paleographic reconstruction, detailed field investigations, in combination with the compilation of geomorphological maps using GIS software and archaeological evidence found in the area, we attempted to reconstruct the fluvial evolution of Vouraikos river and identify the major geomorphological factors that led to, and influenced it. Finally, the link between cultural activities and sedimentary processes is also studied. The recorded environmental variations had a great impact on the geomorphological shaping and instability of Kalavrita
\end{abstract}


plain and Vouraikos river and are being reflected on the buried settlement. Sediment fluxes were high enough to form strath terraces, while local tectonics aided in the strath and fill terrace creation. Smaller and younger strath terraces, formed during increased sediment supply periods, when the valley was at a higher level.

\section{Keywords}

Climatic Changes, Geoarchaeology, Geomorphology, Strath Terraces, Kalavrita Plain, Vouraikos River

\section{Introduction}

Fluvial systems are characterized by a notable variety of physical conditions that enable their adaptation to the morphological changes, due to their high dynamics combined with environmental, especially climatic, influences. Therefore, river systems that are being affected by environmental factors, reflect this influence by adjusting their channels. These adjustments are representative of the state of equilibrium of the fluvial systems and their adaptation to their changing environment [1].

During the middle (and part of late early) Pleistocene, the Hellenic region has undergone some major palaeogeographical alterations that had as a result the formation of intermountain basins and of the recent coastal plains and capes that we see today. The geomorphological and palaeogeographical evolution of this kind, was closely connected to the tectonic condition and geodynamics of the Mediterranean region.

The continental and marine environment in this area has evolved while affected by these palaeogeographical alterations and synchronously was also affected by the periodical Quaternary climatic oscillations in the Mediterranean [2] which also led to sea level oscillations in the same region [3]-[8].

Our study area is located approximately at N331000-E4210000 of the GGRS87 coordinate system and constitutes the upper and middle flow part of the Vouraikos river and the surrounding area, located near the NW border of Chelmos (Aroania) mountain $(2341 \mathrm{~m})$ in Northern Peloponnese (Figure 1), near the town of Kalavrita. The area is part of the Skepasto basin [9] or the Kalavrita basin, according to Trikolas [10].

The Skepasto basin constitutes a graben with a general E-W direction which was developed NW of Kalavrita town [9].

The aim of this paper is to reconstruct the fluvial evolution of Vouraikos river in the study area and identify the major geomorphological factors that led to, and influenced this evolution. Also, a secondary aim is to collect evidence on the environmental conditions that governed the study area and discover how the studied fluvial system was affected by the geomorphological changes that led to 


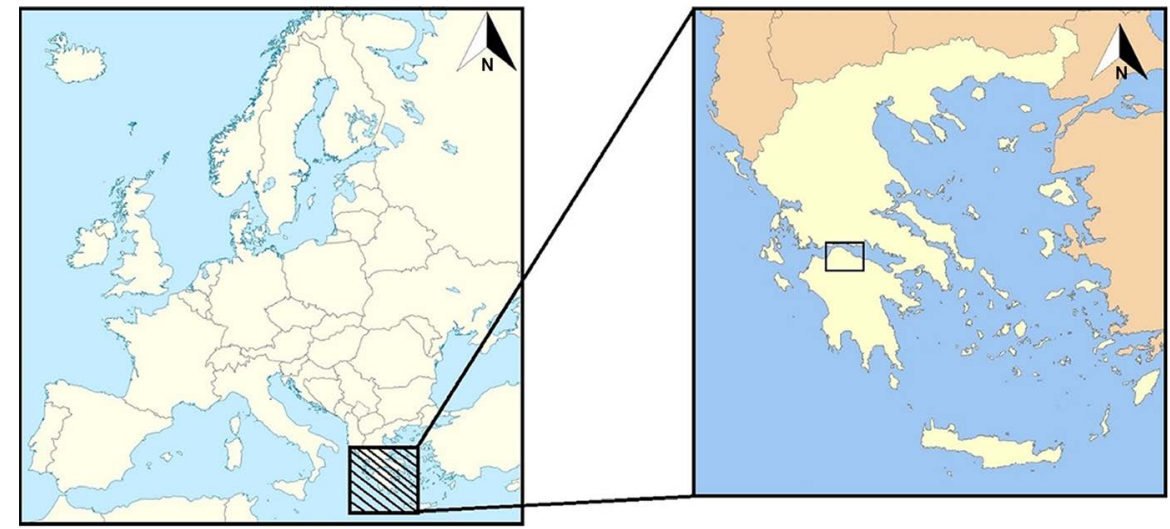

Figure 1. View of the study area location.

channel adjustments and how these changes affected human activity. These environmental conditions reflect wider environmental and climatic changes that took place in the Mediterranean during the investigated period and as such, it can be a topic of wider interest. These tasks will be carried out with the assistance of field investigations, geomorphological mapping, archaeological evidence found in the study area and GIS analysis.

The most obvious way in which geoarchaeology may be used as tool in geomorphology is by dating the erosional and depositional events and also by identifying and reconstructing the climatic factors which influenced the study area. The study focuses especially on the period of the archaeological evidence of the $10^{\text {th }}$ and the $7^{\text {th }}$ century B.C. That is translated to be between Early Protogeometric Period and Early Archaic Period and coincides with the climatic changes observed during the Holocene period.

\section{Methodology}

A landscape in general, is being distinguished by the characteristic morphologies that govern its' shape. These morphologies are mainly caused by tectonic forces such as tectonic uplift, sedimentary processes like erosion and sediment transport and climate conditions. These processes formed distinctive topographic signatures [11] that characterize the Earth's surface. Therefore, a geomorphological approach was adopted in this case, in order to investigate the Vouraikos' river channel adjustments and general evolution during the Holocene that occurred at the Skepasto basin.

This work focuses on the land-surface and fluvial development of the study area while taking into account the local geology and the major climatic changes that occurred during Holocene period. A paleographic reconstruction was carried out aiming at recognizing the submerged and emerged areas and at describing and interpreting the major morphological features and environmental alterations regarding the study area and especially of Vouraikos river channel. That was achieved with on the field geomorphological and geoarchaeological 
mapping and geoarchaeological prospecting, as we were able to take advantage of the archaeological excavations, taking place at an area of approximately 1.5 $\mathrm{Km}^{2}$.

Finally, detailed field investigations of the Holocene stratigraphy and sedimentological study in combination with map and aerial photo interpretations and the compilation of Geomorphological maps using GIS software, provided valuable information about the geomorphological evolution and features of the study area and an insight of the evolution of the Vouraikos' river channel. The latter was achieved by using DEMs (GDEM V2) with 30 -meter postings and $1 \times 1$ degree tiles, produced by NASA's ASTER (Advanced Spaceborne Thermal Emission and Reflection Radiometer)-EOSIDS (Earth Observing System-Data and Information System) program.

The DEMs were checked and corrected in order to be further processed. A hydrological model in the studied area was produced using ESRI'S software package, ArcGIS and all the relevant data produced by the study were then overlain on the final map. The overlaid geology of the area was produced by field study, while taking into account the works of Poulimenos [9], Doutsos \& Poulimenos [12], Zelilidis [13] and Flotté et al. [14].

\section{Geological-Geomorphological Setting}

The study area is situated at an altitude of $800 \mathrm{~m}$ as a part of the Corinth Rift. It comprises of Mesozoic, Upper Triassic-Jurassic limestone and dolomite of the Tripolitsa unit of the External Hellenides and Plio-Pleistocene fluvio-lacustrine sequences. Alongside the south margin of the Corinth Rift, the intensely fragmented mountains of northern Peloponnese expose extensional half-grabens, which are bound by WNW/ESE and NNE/SSW normal faults [12] of listric geometry that assisted the uplift-induced valley incision in the study area [12] (Figure 2). The inland part of the aforementioned rift is about $40 \mathrm{~km}$ wide and $120 \mathrm{~km}$ long and it includes seismically active and inactive faults along with the correlated sediment fill [12]. Therefore, it provides an opportunity to assess the structural, stratigraphic and morphological evolution of the rift and consequently, to give an insight into development process of the basin in study (Skepasto basin). A large number of the non-marine sequences are not dated accurately and reliably. Consequently, units among adjacent fault blocks can only be lithostratigraphically examined and associated with each other [15].

The tectonic structure of Peloponnese is characterized by thrust nappes and normal faults [12].

The main fluvial system in the area is the Vouraikos river with its tributaries and a drain-age pattern in the study area runs SW-NE.

The area around of Skepasto village consists of Plio-Quaternary and Holocene sediments. It is believed by Poulimenos [9] that the Plio-Quaternary sediments are of braided river origin. Uncomfortably resting stream Holocene sequences with maximum thickness of about $5 \mathrm{~m}$, cover the Plio-Quaternary sediments. 


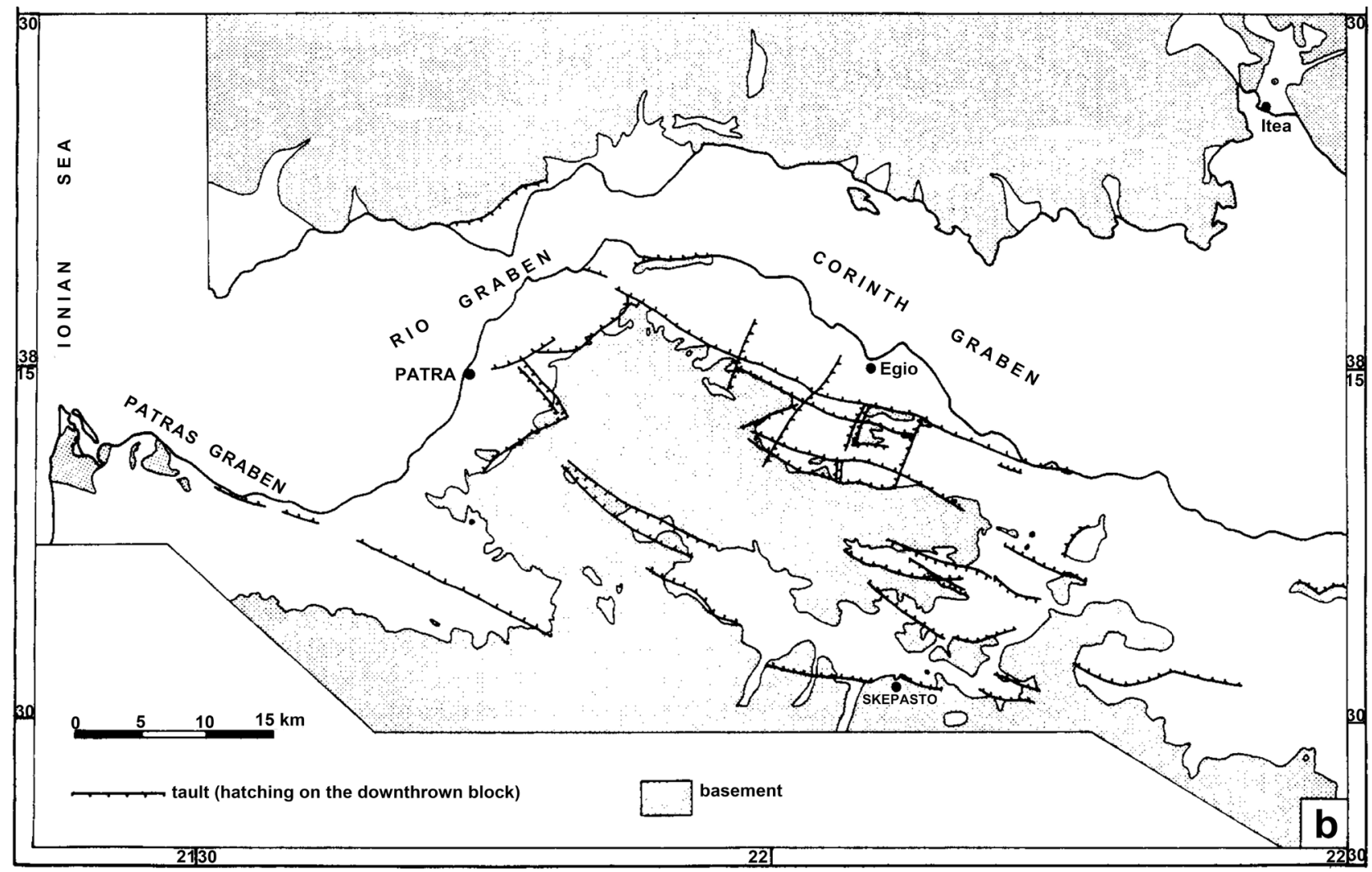

Figure 2. Tectonic map of the active faults in the general study area ([12], with edits).

The geomorphological landscape is mainly characterized by alluvial deposits (Figure 3). Other important geomorphological features in the area are the fluvial terraces, the alluvial fans, the fluvial scarps near the river, and their main rill washes.

The alluvial plains in the area are becoming wider as we move towards the east. One of the important features of the Xerocampos valley (Figure 4), in correspondence to the archaeological site, is the asymmetry of river position in the valley. The river in fact is shifted to the SE by the existence of the alluvial fan located on the slope to the N/NW of the valley. The whole set of these geomorphological characteristics was present in the area before the construction of the settlement which was buried by fluvial activity.

The geomorphology of the area is directly influenced by structures formed on the bedrock and we are trying to assess how they were impacted by the changes of the climate during the Quaternary and the general tectonics of the area.

Mediterranean climate characterizes the area under study. Specifically, the period of limited precipitation, i.e. dry period, is during the summer months. Furthermore, the minimum mean temperature recording for January has a value of $4^{\circ} \mathrm{C}$ and the maximum mean temperature recording for July has a value of $22^{\circ} \mathrm{C}$. The repetitiveness of numerous Holocene major scale climate change events and the important role they play to the shaping of the environment and to humans has been previously pointed out by scientists [3] [17] [18]. 


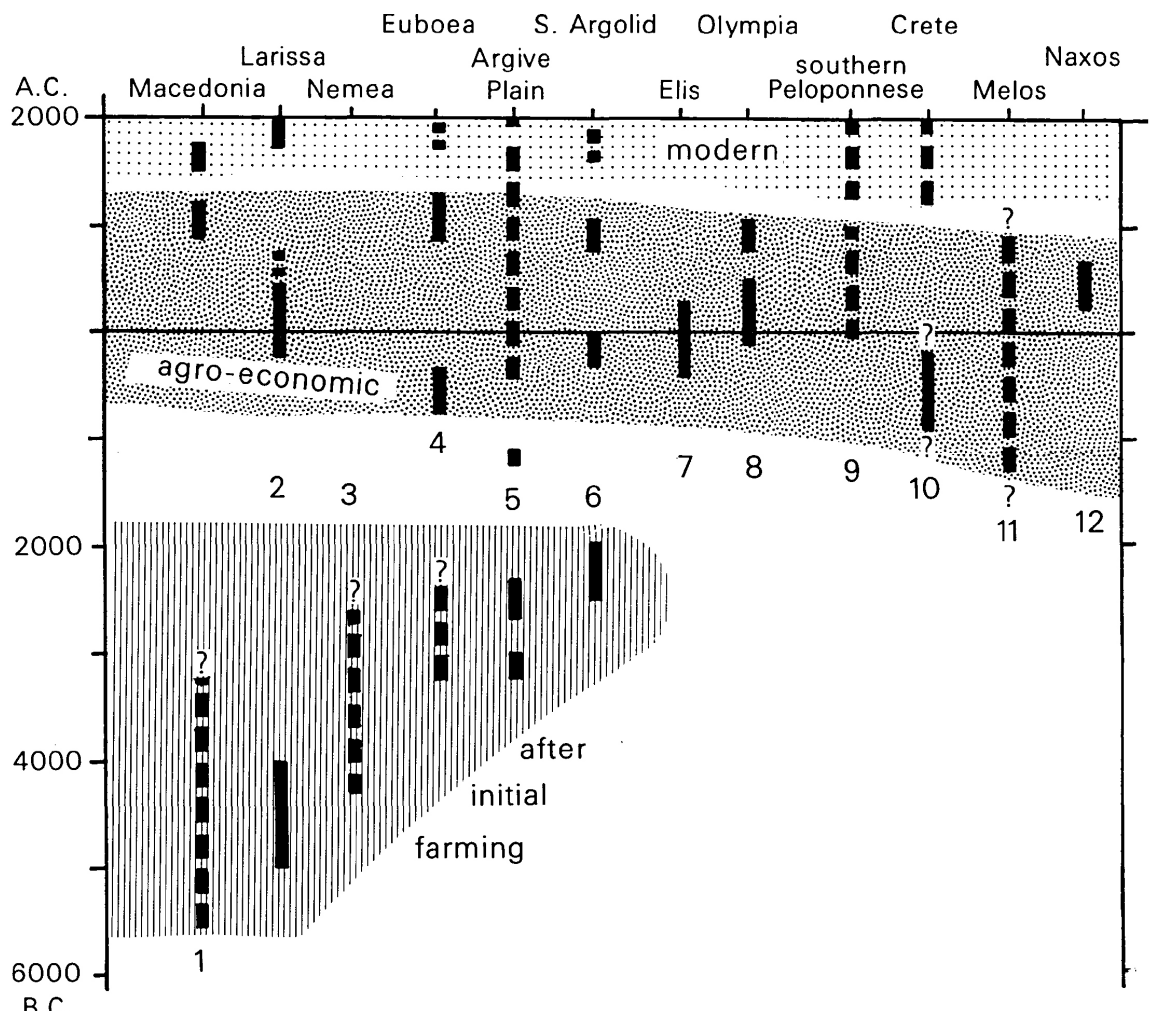

Figure 3. Chronology of alluviation events in Greece and the Aegean [16].

\section{Formation of Strath Terraces}

River terraces are landforms underlain by alluvial deposits and linked to climate change and tectonics [19]. Strath terraces, which are present in the study area, is a term used to describe their erosional nature [20]. These terraces represent the outcome of the interaction between the sum of the geomorphological processes that led to the bottoms of the valleys being carved by graded or steady state longitudinal profile, while a river synchronously is lowering and widening its channel. Strath terraces are characterized by distinctive, almost horizontal erosional bases that most of the times are carved into the bedrock and are covered by a thin alluvial cover. As bedrock, constitutes any substrate into which the river valley is being developed. That includes soft, poorly consolidated sediments that can make the difference between river alluvium and bedrock difficult to distinguish.

This difficulty may be a result of a major change in the climate in the area [21]. A fluvial equilibrium takes place as a result of slowed or even stopped uplift, environmental and climatic changes or because of an alteration of the bedrock type due to local geology. Rivers, were strath terraces have formed, are characterized by aggradational periods that should be either comparatively small, in comparison with the incisional periods, or even absent. Moreover, the formation of the terraces indicates repeating phases of incision followed by phases of planation. 


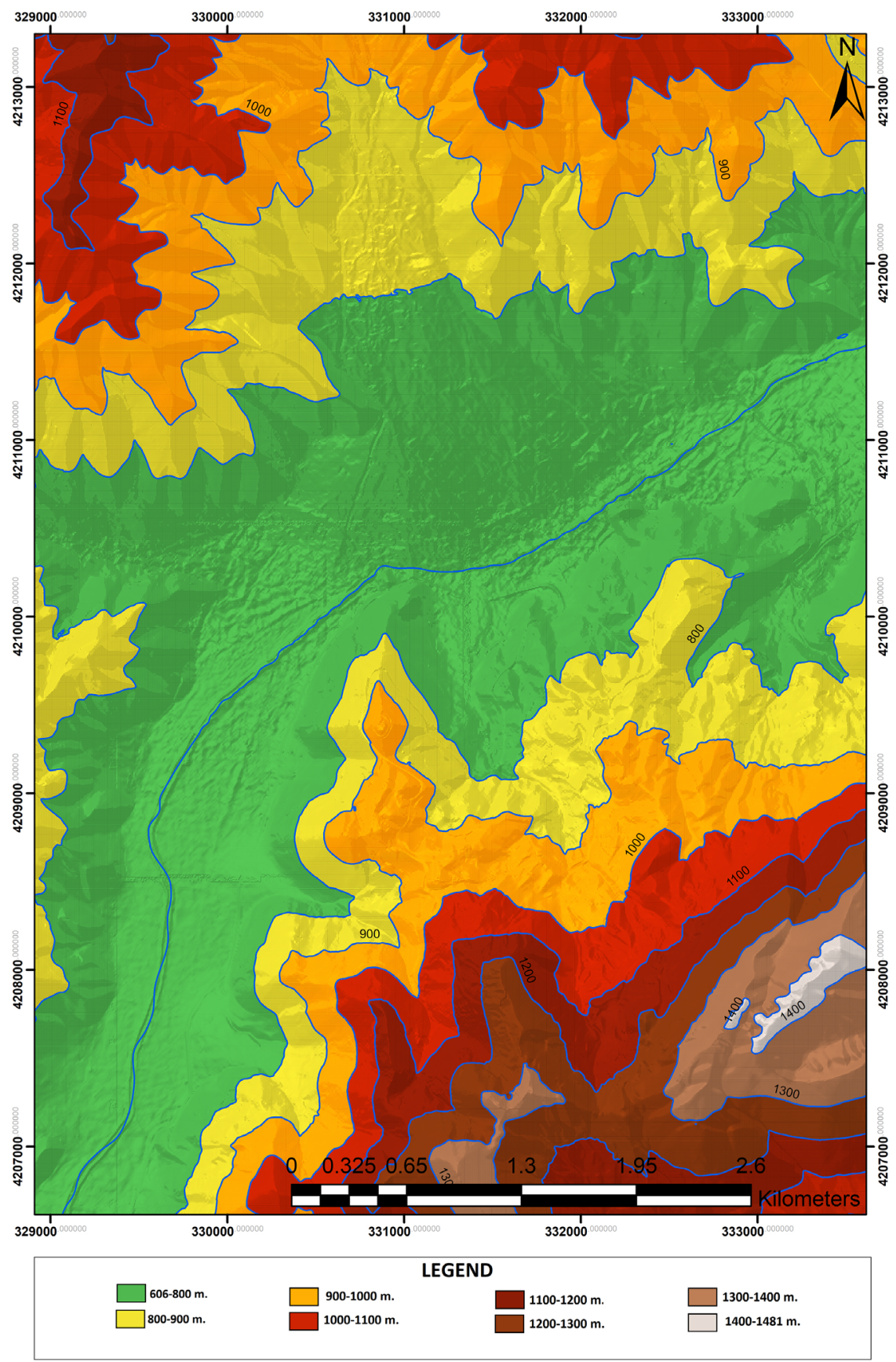

Figure 4. GIS created topographic map of the study área. Coordinate system is GGRS87.

\section{Human Settlement and Sedimentary Cover}

The fluvial evolution in our study area is one important aspect in our effort to understand the background of the human settlement that was uncovered. $\mathrm{Nu}$ merous attempts have been made, in order to cross date geomorphological, tectonic and generally geological evidence with archaeological data.

During Holocene, the study area was almost uninterruptedly inhabited where the alluvial fan is located, along the riversides of the stream. Cyclic flooding events 
as observed during fieldwork (Figure 5) and archaeological excavations, have covered the site over and over again, mainly under layers of mud, sand and gravel. Some remnants of settlements, indicating human activity by several groups of people, were also found covered with alluvial sediments.

These cyclic events are also supported by the findings of Stamatopoulos \& Evelpidou [21]. A settlement and archaeological finds of younger age $\left(3^{\text {rd }}-2^{\text {nd }}\right.$ century B.C.) were buried as a result of fluvial migration and flood events. These findings were discovered approximately $17 \mathrm{~km}$ south of our study area, at the ancient city of Kleitor.

The deposits are generally very poorly sorted with an indistinctive bedding (Figure 5). Particle sizes are ranging from clay to gravel and boulder sized clasts up to $2.5 \mathrm{~m}$ in thickness. The very first meter of the sedimentary cover in the study area were exposed or where it was excavated because of the unearthing of the human settlement, suggests that it most probably was the result of deposition from fairly viscous debris flows.

At present time, human activity such as the creation of irrigation channels in Xerocambos, near Skepasto village, $2 \mathrm{Km}$ NW of Kalavrita town, had as a result, archaeological artefacts to be unearthed. Between the years 2001 and 2008 archaeological excavations were carried-out in an area of approximately $1.5 \mathrm{Km}^{2}$ on the NE higher fluvial terrace of Vouraikos River. Buried archaeological artifacts such as in situ pottery and traces of a constructed settlement, which was protected by a wall, were discovered by Alexopoulou in 2009 [22] (Figure 6).

The protective wall has a height of $0.80 \mathrm{~m}$ and a width of $2 \mathrm{~m}$. The artefacts were found $1.25-1.8 \mathrm{~m}$ (Figure 6) below the present land surface, covered by

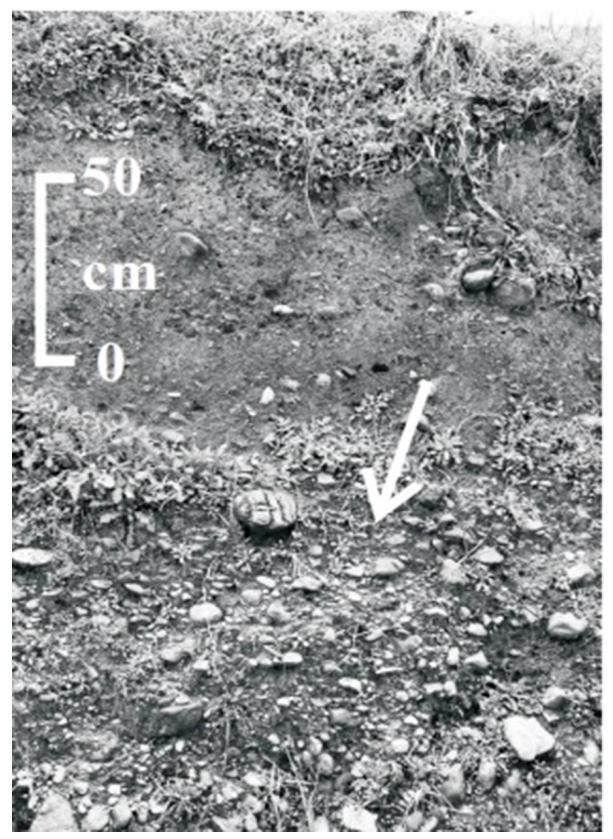

Figure 5. Detail of early holocene debris flow deposits in the study area. The deposits are better represented in the indicated area (arrow) of the figure. 


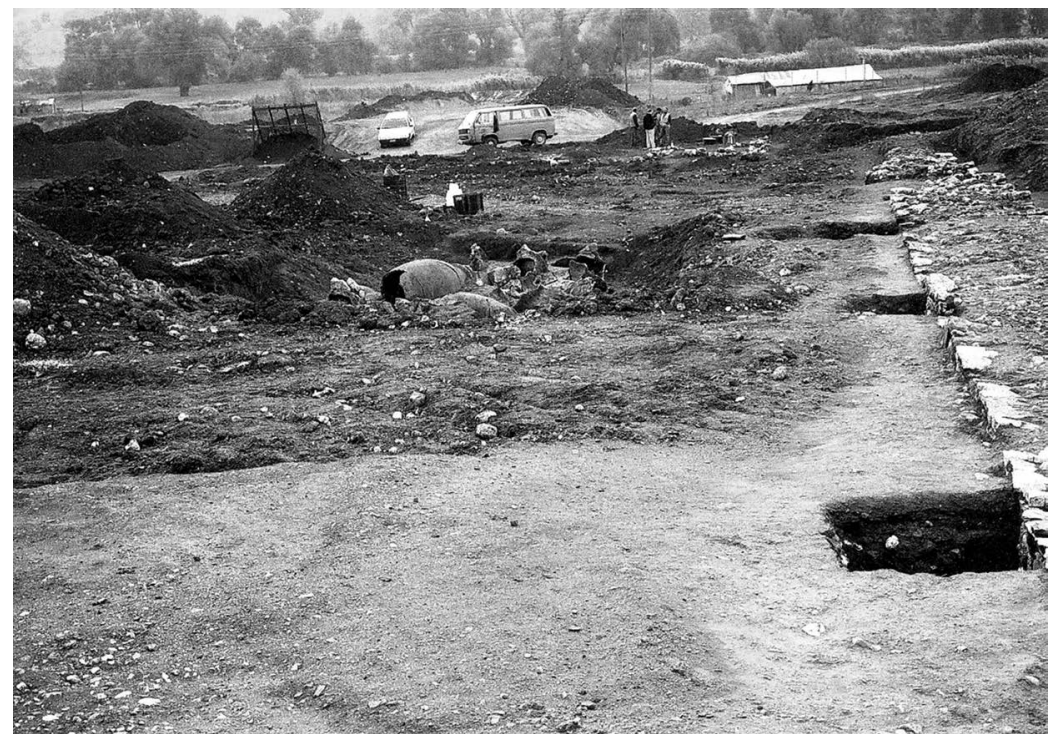

Figure 6. Archaeological artifacts uncovered buried into holocene alluvial deposits of Vouraikos river (Kalavrita plain, northern Peloponnese).

silty gravels, fluvial sediments and about $4 \mathrm{~m}$ higher than the present river flow bed (thalweg). According to Alexopoulou [22], the age is estimated to be between the $10^{\text {th }}$ and the $7^{\text {th }}$ century B.C. That is translated to be between Early Protogeometric Period and Early Archaic Period.

\section{Results}

Knowledge of the morphochronological evolution of a study area is often difficult to assess, in view of the lack of accurate geological constraints. The presence of Plio-Pleistocene tectonic and stratigraphic products in combination with the existence of Geoarcheological data in the Kalavryta plain allows us to reconstruct the geomorphological processes.

Cyclic flooding events, triggered by climate change in the Mediterranean region and consequently in the study area, have been studied in this paper. Archaeological artifacts and findings in general, assisted to connect and analyze them chronologically with these flooding events and this relation will be analyzed in the following chapter.

Additionally, the findings have been located under a sedimentary cover with particle size, orientation, bedding, sorting, thickness and general characteristics that correspond to more than one incidents of debris flow. This deduction is being verified by numerous particles of large size (up to boulder size) that were found to be present in a matrix of smaller particles up to the size of gravel. These flooding events characterized the area geomorphologically as they were crucial to its formation and evolution. The findings also verified the age of the terraces creation.

The study area in and near Skepasto basin appeared to be full of human activity during ancient times. 
That is an indication that the burial has happened as a result of flooding that forced the population to abandon the settlement [22]. People in the area at this time were aware of the flooding danger and probably has happened before, as indicated by the construction of a wall [22], as an effort to protect their properties from being destroyed.

The aforementioned settlement is situated on a preexisting alluvial fan of a probably Early Holocene age, cut by linear erosion and transformed in a terrace. The altered environmental and climatic conditions from glacial to eventually warm humid drastically reduced slope degradation processes and induced related aggradations of riverbeds. This fan was the result of post-glacial stream sedimentation due to the abundance of clastic material of glacial origin present in the valleys floor and distributed by the stream. Probably climatic variations during middle Holocene allow the stream to cut a small erosional valley in the alluvial fan and alluvial plane: the main order of terrace was formed.

The recent findings are shown in Figure 7 which depicts a palaeogeographic reconstruction of the local geology along with the geomorphological processes described, that govern the current shaping of the area and the location of the settlement. The alluvial plains that widen eastwards are observed, along with the rest of the major geomorphological features that govern the area. These are the fluvial terraces alternating from the north to the south bank of Vouraikos river, the alluvial fans, the fluvial scarps in proximity with the bank and the main rill washes.

The river bank is currently moving to the SE, affected by the local geology as shown in the reconstruction and the geomorphological and sedimentary processes of the alluvial fan, coming from a left slope direction towards the right side of the valley.

Also, the local geology of the study area is being shown as a result of map interpretation and fieldwork investigations. The former as well as the latter also revealed the existence of two large normal faults in the area. The northwest one, having a NW-SE orientation extending at a distance of $2 \mathrm{~km}$. The south one, with a general direction of $\mathrm{W}-\mathrm{E}$ extends at a distance of $3.2 \mathrm{~km}$ and cuts through Vouraikos river channel.

The area of main interest is covered with braided river and alluvial fan deposits.

\section{Discussion}

The degree of the impact and the importance of the climate in relation with the geomorphological and sedimentological processes, has been under debate for quite some time [23]. Penck \& Bruckner [24] first deduced that there is a connection between climate change and the fluvial terraces formation.

Both aggradational (fill) and bedrock (strath) terraces occur in the study areas river network of Vouraikos. The greatest obstacle to reconstruct the timeline and extract conclusions about the creation of these terraces is that of chronology and 

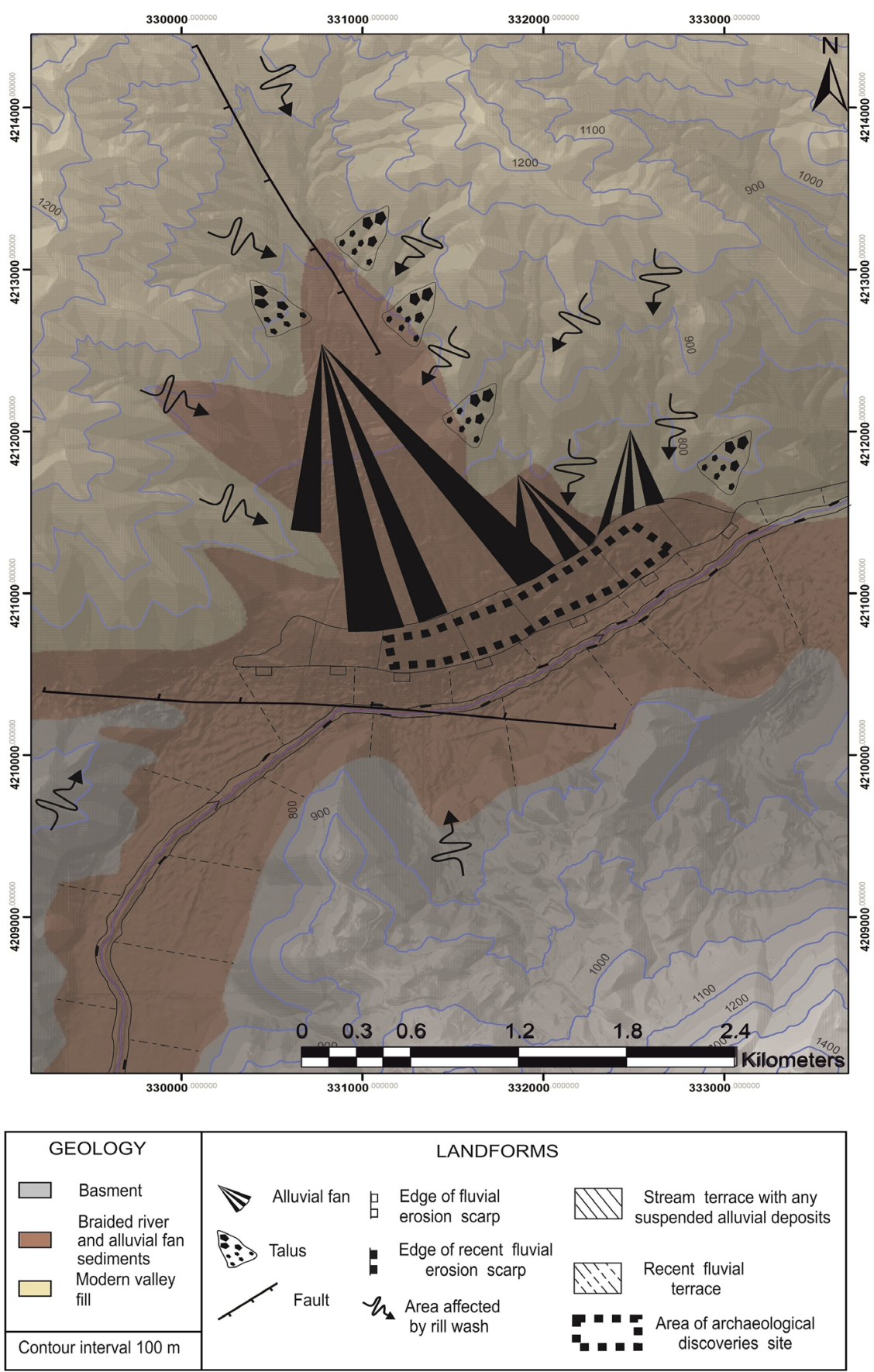

Figure 7. Geomorphological map and reconstruction of the major geomorphological features of the study area.

climate fluctuations. A terrace's creation can be defined by its age and its position into the glacial and interglacial climatic record and by the tectonic environment into which they are being formed. Also, time and age enable age-related comparisons between strath and fill terraces and facilitates links to already documented tectonic and climatic events. It is a deciding factor to identify whether or not the terraces formed when these events took place. Strath terraces are usually main- 
tained in better condition at higher altitudes. On the other hand, fill terraces are usually best maintained at lower altitudes [25]. Additionally, the construction of the timeline of the major events taken place in the area is being assisted by the archaeological findings.

In spite of the wide use of strath terraces in geomorphology (both fluvial and tectonic), it's still not clear the conditions in which the planation of a strath terrace takes place. There is a difficulty to deduce the rules that govern the mechanisms of the strath terraces formation along with the duration of such processes and their exact age based solely on field investigation and observations. That is because terrace sequences are difficult to date as they constitute fragmented and incomplete records that were created in climatic, morphological and fluvial conditions that are different from the current ones.

Strath and fill terraces have been linked to peak glacial advances [24] [26] [27]. They have also been linked with deglacial transitions [28], and also with processes that are not related to glacial processes, like the monsoon intensification [29] or the migration of sediment waves [30].

The large-scale uplift which has occurred during the Plio-Quaternary in Northern Peloponnese [12] has also played a significant morphogenetic role in the area.

Phases of Holocene valley alluviation for many countries around the Mediterranean have been described and ascribed either to human activity and climatic change [21] [31] [32] [33].

The climatic change in the area is directly connected to the glacial fluctuations and the topographic position of Vouraikos river in correlation with the glacial morphology.

The climatic and therefore the glacial fluctuations are recorded as advances and retreats of the ice line which in this case is rather useful as a result of the high altitude (800 m.a.s.l.) and the topography of the Kalavrita plane positioned $14 \mathrm{~km}$ NE of Helmos mountain.

Helmosmountain, is characterized by Tymphian [34] glacial and periglacial morphology, represented by glacial circles and moraine deposits and is related to the last glacial maximum [35]. In fact, at the time interval of the studied settlement (3000 - 2700 B.P.), the Helmos glacier was extinct [36].

The altered climatic conditions from glacial and periglacial to warm and humid, drastically reduced slope degradation processes and induced related aggradations of riverbeds [21]. This climate fluctuation hypothesis is supported by deep-sea core stratigraphy analysis (in this case core LG21 extracted from the Aegean Sea) (Figure 8). This study shows the profusion (\%) of Aegean core LC21 planktonic foraminiferal species that have a natural liking of warm water [37] which is indicative of the climate fluctuations through a period of more than 11.000 y. B.P., clearly depicting the shifts form cold and dry to warm and wet periods. 


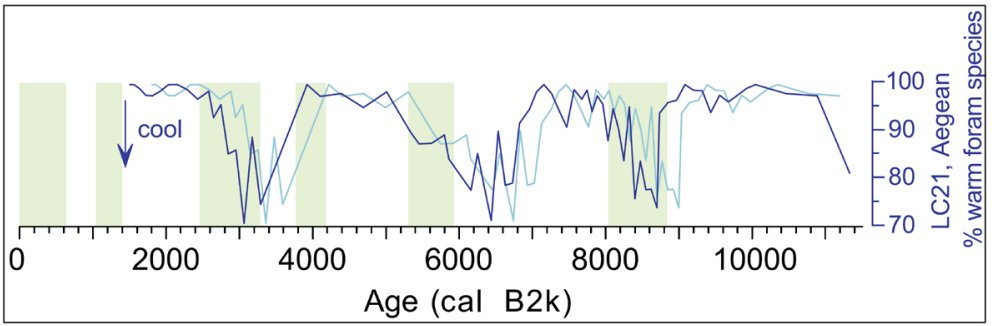

Figure 8. Climate temperature fluctuations depicted as relative abundance (\%) of LC21 planktonic foraminiferal species with warm-water affinities. Green bands represent timing of RCC (Rapid Climate Change). Light line represents original calibrated AMS ${ }^{14} \mathrm{C}$ chronology and heavy line indicates maximum (three to four centuries) correction required to match the Minoan eruption of Santorini to its actual age ([37] with edits).

It is evident that between 3000 and 2700 yrs B.P. the climate conditions in the study area were cold and humid and subsequently to this interval, the climate was rapidly warming till a warm peak around 2200 yrs B.P.

Additionally, the uplift-induced valley incision [12] was affected by the climate change episodes during the Quaternary (Figure 9). As a result of this relation between geomorphological features and climate, the first order fluvial terraces were emplaced in the area while the surface of many terraces was aggraded during flood events.

Successively, the study area underwent a climate change resulting to flooding events commonly present in dry warm climate conditions and intense concentrated rainfall. As consequence, high amount of sediments was deposited in episodes of concentrated rainfall and related flash flood events. Events that had as a result the burial of the human settlement.

Strath terraces are created when sediment fluxes are high enough to cover the channel bed. Additionally, discharge has to be low enough in order for the sediment not to be able to move and expose the bed to be eroded. Finally, lateral erosion has to be greater than vertical incision [38].

High sediment flow that was present during deglaciation period [39], could easily create such conditions that favor strath formation. In the case of an easily, through abrasion, erodible bedrock, plucking and cavitation, wide straths can be rapidly generated.

As it was already mentioned, the study area consists of Plio-Quaternary and Holocene sediments (braided river sedimentary sequences) and uncomfortably resting Plio-Quaternary sediments that are being covered by stream Holocene sequences. Local tectonics have an effect on the sediment supply which fluctuates along the rivers channel length along with the creation of strath terraces which are carved into the bedrock and also fill terraces. The former are created during a process that takes place as sediment flow values become lower than the ones of the transports capacity. Then, the bed is re-exposed and fluvial incision restarts, converting the strath to a strath terrace. Locally, a thin veneer of alluvium on the top of them is observed. 


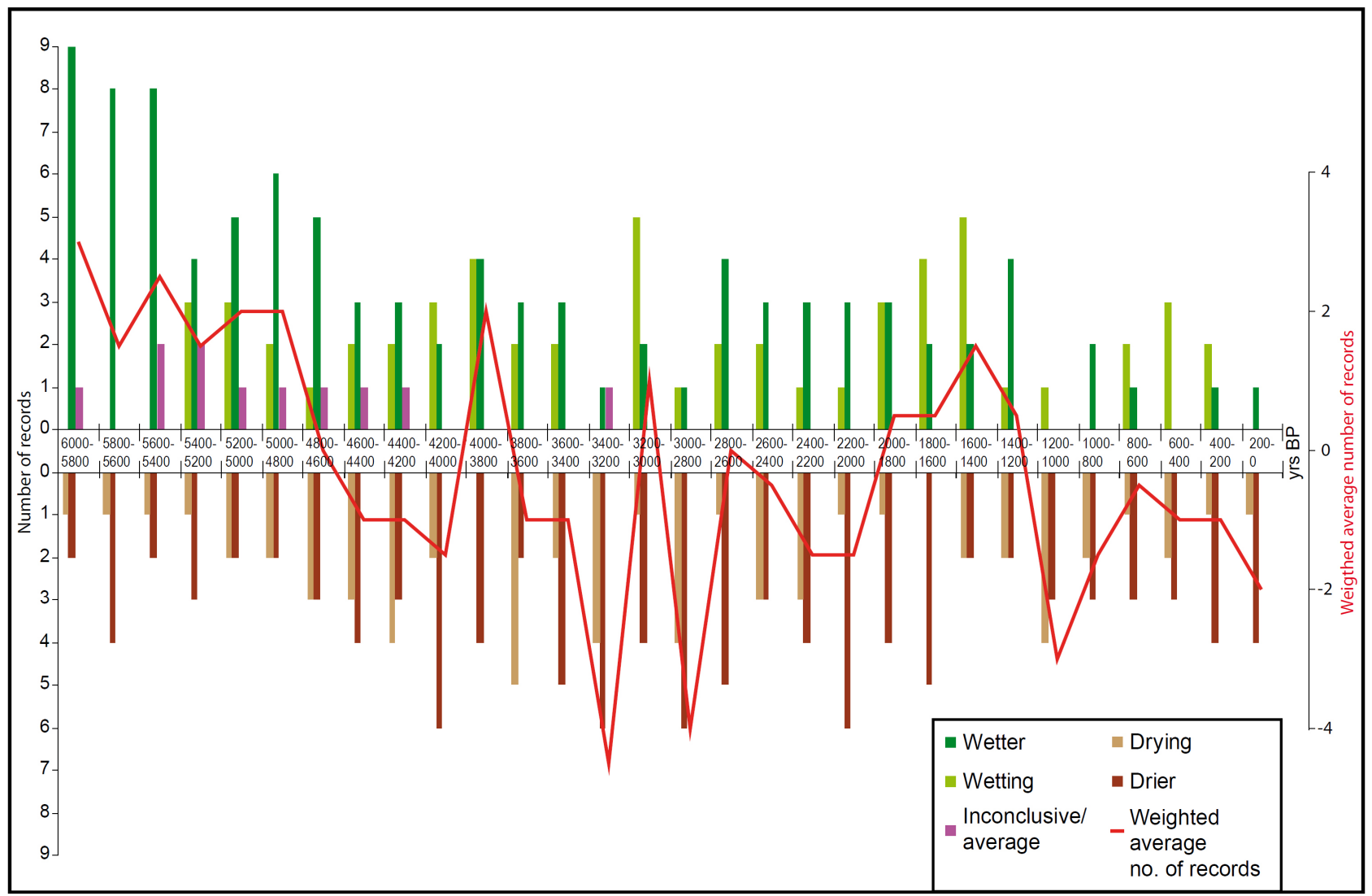

Figure 9. The results from the temporal analysis of paleoclimate records showing wetter and drier conditions from the eastern Mediterranean. Each bar represents the number of records in each 200-year time slice that show either above (wetter) or below (drier) than average conditions, or going from either drier to wetter (wetting) or from wetter to drier (drying) conditions. Average line (red) is calculated as follows: dark green bars were assigned a value of +2 , light green bars were assigned a value of +1 , dark brown bars were assigned a value of -2 and light brown bars were assigned a value of -1 . For each 200 -year period an average value was calculated based on the assigned values [40].

The bedrocks lateral erosion is the governing process and could have such a duration that is enough to produce sloping surfaces under active channels.

Given enough time, there is a possibility for pediments to form. These major strath terraces constitute the landform of the fundamental stream-terrace. Smaller strath terraces, which are more recent, formed when the river overflowed its banks and beveled the bedrock, during the aforementioned increase of the supplied sediment, while the valley was at a higher altitude.

Figure 9 shows evidence of wet conditions in the eastern Mediterranean region for a period ranging from 6000 to 5400 years B.P. These conditions are probably corresponding to the insolation maximum of the northern hemisphere during early Holocene. Conditions are still more wet than average with a tendency to become drier during 5400 and 4600 B.P. Around 5000 years B.P. a wet period is distinctively shown followed by a transitional period from 4800 to 4400 . A drier period is shown to be present in between 4600 to 1400 B.P. [40].

The climatic reconstruction attempted, is also backed up by the findings of Heymann et al. [41] and especially the $\mathrm{Rb} / \mathrm{Sr}$ ratio for Lake Stymphalia in North 
Eastern Peloponnese, $25 \mathrm{~km}$ south of the Gulf of Corinth, neighboring our study area (Figure 10). If the $\mathrm{Rb} / \mathrm{Sr}$-ratio is elevated that represents climatic conditions of higher humidity, a fact that means that solar activity was high [41]. On the other hand, if the $\mathrm{Rb} / \mathrm{Sr}$ ratio is lowly, that represents drier climatic conditions as a result of the lower solar activity. These ratio values can also be used to identify pedogenesis and chemical weathering in a catchment area [41] [42] [43]. It is worth mentioning that the dry climatic conditions of the Late Glacial (15 - 11.7 ka B.P.) shift during the Early Holocene (11.7 - 8 ka B.P.) to a generally wet climate, especially around 12.1 kacal B.P. with dense vegetation and an increase of clastic/clay material fluvial transportation, played a significant role in the shaping of the fluvial terraces and alluvial fans.

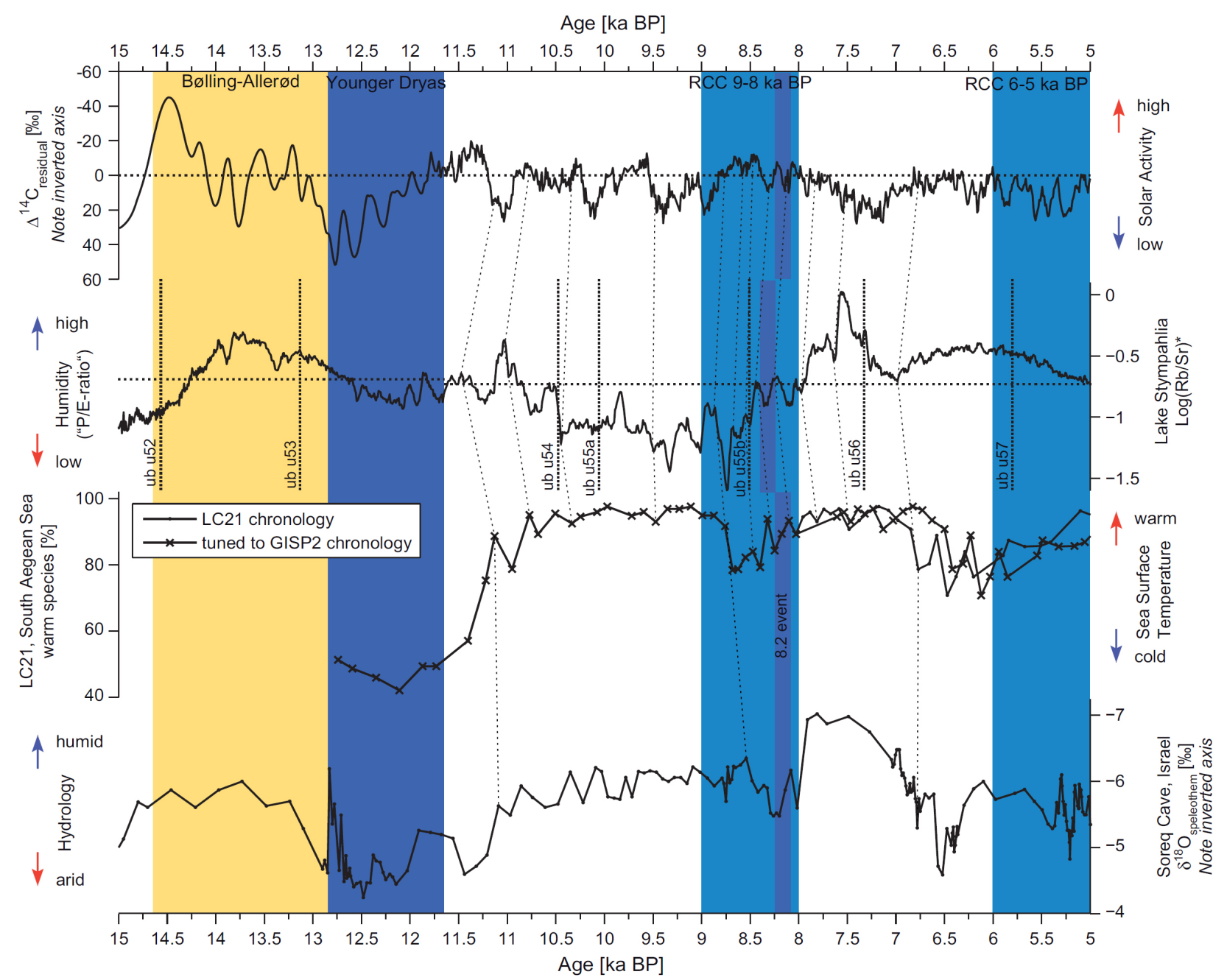

Figure 10. $\mathrm{Rb} / \mathrm{Sr}$ from Lake Stymphalia sequence in relation to the warm species record of core LC21 from the Southern Aegean Sea indicating temperature changes, the stable oxygen-isotope record of speleothems from Soreq cave, Israel indicating humidity changes, and the $\mathrm{d} 14 \mathrm{C}$ record which depicts solar activity. Dashed vertical lines represent gradational unit boundaries in core STY-1. The shaded yellow interval indicates the Bøllinge-Allerød. Shaded blue intervals indicate the Younger Dryas cold period and Holocene time periods of rapid climate change (RCC). Offsets in ages between LC21, Soreq cave and Lake Stymphalia are due to the fact that the LC21 core chronology is based on AMS 14C dates and synchronization to Greenland ice core records, and the Soreq cave speleothem chronology is based on UeTh ages ([41], with edits). 
The wet conditions, with small interruptions, continue during Mid-Holocene (8 - 5 ka B.P.) while climate conditions in area became similar to the present day after 7 kacal B.P. Human impact on sedimentary processes and dynamics in the study area becomes important during the Bronze age (after 5 ka B.P.) [41] [44].

\section{Conclusions}

Comparing the geomorphological and archaeological data enabled us to comparatively date the fluvial forms of the study area and also enabled the stages of geomorphological evolution to be defined. Xerocambos plain in Northern Peloponnese was geomorphologically active between 10th and 7th century B.C. and was buried beneath $1.5 \mathrm{~m}$ thick fluvial sediments.

Before the $10^{\text {th }}$ and the $7^{\text {th }}$ century B.C. (Early Protogeometric Period - Early Archaic Period), the study area was generally affected by cold humid climatic conditions, like numerous other parts of Greece and the Mediterranean.

The recorded environmental variations in the general study area had a great impact on the geomorphological shaping of Kalavrita plain and especially Vouraikos river channel. The analysis identified and confirmed a shift from glacial and periglacial dry conditions to warm and humid conditions.

As a result, reduced slope degradation processes and induced related aggradations of riverbeds are the main geological processes that characterized the area. Additionally, due to the uplift-induced valley incision in combination with the climate shift, fluvial terraces were created in the area.

Subsequent widespread flooding events deposited high amount of sediments, in episodes of concentrated rainfall and related flash flood events, shaping the present-day fluvial system along with alluvial fans and terraces. This climate shift is reflected on the burying of the settlement and the findings of human activity in the alluvial deposits.

The Xerocambos settlement was surrounded by a flood-protection wall in order for structures to be protected in the case of these events [22]. This settlement was situated on a preexisting alluvial fan of probably Early Holocene age, cut by linear erosion and transformed in a terrace.

Sediment fluxes were high enough to form strath terraces as they covered the channel bed of Vouraikos river while discharge was low enough having as a result lateral erosion being greater than vertical incision and promoted strath formation.

We also have to take the local tectonics under consideration that also affect the sediment supply and aid the strath and fill terrace creation.

The connection of cultural activities with tectonic and sedimentary processes is especially well-expressed in this study case. The characteristics of archaeological traces provide the geomorphological tools for studying post fluvial processes and hydrological conditions. Additionally, these archaeological traces can provide evidence regarding the study of the areas land use and development, reworked sedimentary deposits and most importantly, the paleoenvironment conditions of the area. 


\section{Acknowledgements}

We would like to express our appreciation to Prof. Marcello Schiattarella for the fruitful and incisive discussion during the study and also for his encouragement and help to submit this work.

\section{References}

[1] Aucelli, P., Fortini, P., Rosskopf, C., Scorpio, V. and Vincenzo, V. (2011) Recent Channel Adjustments and Riparian Vegetation Response: Some Examples from Molise (Italy). GeografiaFisica e Dinamica Quaternaria, 34, 161-173.

[2] Santagelo, N., Di Donato, V., Lebreton, V., Romano, P. and Ermollu, E.R. (2012) Palaeolandscapes of Southern Apennines during the Late Early and the Middle Plestocene. Quaternary International, 267, 20-29. https://doi.org/10.1016/j.quaint.2011.02.036

[3] Pirazzoli, P.A. (1991) World Atlas of Holocene Sea-Level Changes. Elsevier Science, Newton.

[4] Lambeck, K. (1995) Late Pleistocene and Holocene Sea-Level Change in Greece and South-Western Turkey: A Separation of Eustatic, Isostatic and Tectonic Contributions. Geophysical Journal International, 122, 1022-1044. https://doi.org/10.1111/j.1365-246X.1995.tb06853.x

[5] Lambeck, K. and Bard, E. (1999) Sea-Level Change along the French Mediterranean Coast for the Past 30000 Years. Earth and Plametary Science Letters, 175, 203-222. https://doi.org/10.1016/S0012-821X(99)00289-7

[6] Baika, K. (2008) Archaeological Indicators of Relative Sea-Level Changes in the Attico-Cycladic Massif: Preliminary Results. Bulletin of the Geological Society of Greece, 42, 33-48.

[7] Evelpidou, N., Pavlopoulos, K., Vassilopoulos, A., Triantaphyllou, M., Vouvalidis, K. and Syrides, G. (2012) Yria (Western Naxos Island, Greece): Sea Level Changes in Upper Holocene and Palaeogeographical Reconstruction. Geodinamica Acta, 23, 233-240. https://doi.org/10.3166/ga.23.233-240

[8] Fanget, A.S., Bassetti, M.A., Fontanier, C., Tudrym, A. and Berne, S. (2016) Sedimentary Archives of Climate and sea-Level Changes during the Holocene in the Rhône Prodelta (NW Mediterranean Sea). Climate of the Past, 12, 2161-2179. https://doi.org/10.5194/cp-12-2161-2016

[9] Poulimenos, G. (1991) Tectonic Analysis and Sedimentation in the Western Corinth Graben. PhD Thesis, Patras University, Patras.

[10] Trikolas, C.J. (2008) Geological Study of the Wider Area of Aegialia and Kalavryta. PhD Thesis, National Technical University of Athens, Athens.

[11] Tarolli, P. and Sofia, G. (2015) Human Topographic Signatures and Derived Geomorphic Processes across Landscapes. Geomorphology, 255, 140-161. https://doi.org/10.1016/j.geomorph.2015.12.007

[12] Doutsos, T. and Poulimenos, G. (1992) Geometry and Kinematics of Active Faults and Their Seismotectonic Significance in the Western Corinth-Patras Rift (Greece). Structural Geology, 14, 689-699. https://doi.org/10.1016/0191-8141(92)90126-H

[13] Zelilidis, A. (2000) Drainage Evolution in a Rifted Basin, Corinth Graben Greece. Geomorphology, 35, 69-85. https://doi.org/10.1016/S0169-555X(00)00023-4

[14] Flotté, N., Sorel, D., Muller, C. and Tensi, J. (2005) Along Strike Changes in the 
Structural Evolution over a Brittle Detachment Fault: Example of the Pleistocene Corinth-Patras Rift (Greece). Tectonophysics, 403, 77-94. https://doi.org/10.1016/j.tecto.2005.03.015

[15] Collier, R. and Jones, G (2004) Rift Sequences of the Southern Margin of the Gulf of Corinth (Greece) as Exploration/Production Analogues. Search and Discovery. Article 50007. AAPG International Conference, Barcelona, 21-24 September 2003.

[16] Van Andel, T., Zager, E. and Demitrack, A. (1990) Land Use and Soil Erosion in Prehistoric and Historical Greece. Journal of Field Archaeology, 17, 379-396.

[17] Haberle, S.G. and David, B. (2004) Climates of Change: Human Dimensions of Holocene Environmental Change in Low Latitudes of the PEPII Transect. Quaternary International, 118-119, 195-179. https://doi.org/10.1016/S1040-6182(03)00136-8

[18] Berger, J.F., Lespez, L., Kuzucuoglu, C., Glais, A., Hourani, F., Barra, A. and Guilaine, J. (2016) Interactions between Climate Change and Human Activities during the Early to Mid-Holocene in the Eastern Mediterranean Basins. Climate of the Past, 12, 1847-1877. https://doi.org/10.5194/cp-12-1847-2016

[19] Pazzaglia, F.J. (In Press) River Terraces. In: Wohl, E., Ed., Treatise of Geomorphology, Elsevier, Amsterdam.

[20] Bucher, W.H. (1932) "Strath" as a Geomorphic Term. Science, 75, 130-131. https://doi.org/10.1126/science.75.1935.130-a

[21] Stamatopoulos, L. and Evelpidou, N. (2011) River-Bed Evolution during the Holocene in Kalavrita Region (Northern Peloponnese, Greece). Revista de Geomorphologie, 13, 5-8.

[22] Alexopoulou, G. (In Press) Contribution in Archaeology and Topography of the Azania (Northern Arkadia) Province of Kalavrita. University of Thessaly, Department of History, Archaeology and Social Anthropology, Volos.

[23] Vandenberghe, J. (2003) Climate Forcing of Fluvial System Development: An Evolution of Ideas. Quaternary Science Reviews, 22, 2053-2060. https://doi.org/10.1016/S0277-3791(03)00213-0

[24] Penck, A. and Bruckner, E. (1909) Die Alpen imEiszeitalter. Tauchnitz, Leipzig.

[25] Douglas, B., Yixiang, W., Guangjian, W., Jijun, L. and Qingyu, G. (2003) A 900 K.Y. Record of Strath Terrace Formation during Glacial Interglacial Transitions in Northwest China. Geology, 31, 957-960. https://doi.org/10.1130/G19685.1

[26] Molnar, P., Brown, E., Burchfiel, B.C., Qidong, D., Xianyue, F., Jun, L., Raisbeck, G.M., Jianbang, S., Zhangming, W., Yiou, F. and Huichuan, Y. (1994) Quaternary Climate Change and the Formation of River Terraces across Growing Anticlines on the North Flank of the Tien Shan, China. Journal of Geology, 102, 583-602. https://doi.org/10.1086/629700

[27] Pinter, N., Keller, E.A. and West, R.B. (1994) Relative Dating of Terraces of the Owens River, Northern California, and Correlation with Moraines of the Sierra Nevada. Quaternary Research, 42, 266-276. https://doi.org/10.1006/qres.1994.1077

[28] Bull, W.B. (1991) Geomorphic Responses to Climatic Change. Oxford University Press, Oxford.

[29] Pratt, B., Burbank, D.W., Heimsath, A. and Oiha, T. (2002) Impulsive Alluviation during Early Holocene Strengthened Monsoons, Central Nepal Himalaya. Geology, 30, 911-914. https://doi.org/10.1130/0091-7613(2002)030<0911:IADEHS>2.0.CO;2

[30] Weldon, R.J. (1986) Late Cenozoic Geology of Cajon Pass; Implications for Tectonics and Sedimentation along the San Andreas Fault. PhD Thesis, California Institute of Technology, Pasadena. 
[31] Bintliff, J.L. (1977) Natural Environment and Human Settlement in Prehistoric Southern Greece. British Archaeological Reports, International Series 28, Oxford.

[32] Bintliff, J.L. (1982) Palaeoclimatic Modelling of Environmental Changes in the East Mediterranean Region since the Last Glaciation. In: Bintliff, J.L. and van Zeist, W., Eds., Palaeoclimates, Palaeoenvironments and Human Communities in the Eastern Mediterranean Region in Later Prehistory, British Archaeological Reports, London, 485-527. https://openaccess.leidenuniv.nl/handle/1887/7958

[33] Chester, D.K. and James, P.A. (1991) Holocene Alluviation in the Algarve, Southern Portugal: The Case for an Anthropogenic Cause. Journal of Archaeological Science, 18, 73-87.

[34] Hughes, P.D., Woodward, J.C. and Gibbard, P.L. (2006) Late Pleistocene Glaciers and Climate in the Mediterranean. Global Planetary Change, 50, 83-98. https://doi.org/10.1016/j.gloplacha.2005.07.005

[35] Mastronuzzi, G., Sanso, P. and Stamatopoulos, L. (1994) The Glacial Landforms of the Peloponnisos (Greece). Rivista Geographica Italiana, 101, 77-86.

[36] Orombelli, G. (2007) Changes in Alpine Glaciers over the Last 10,000 Years. Quadernidella Societa Geologica Italiana, 1, 5-12. http://www.socgeol.it/files/download/Quaderni/quaderni\%201\%20(2007).pdf

[37] Rohling, E.J., Mayewski, P.A., Hayes, A., ABU-Zied, R.H. and Casford, J. (2002) Holocene Atmosphere-Ocean Interactions: Records from Greenland and the Aegean Sea. Climate Dynamics, 18, 573-592.

[38] Hancock, G.S. and Anderson, R.S. (2002) Numerical Modeling of Fluvial Strath-Terrace Formation in Response to Oscillating Climate. Geological Society of America Bulletin, 114, 1131-1142.

[39] Church, M. and Slaymaker, O. (1989) Disequilibrium of Holocene Sediment Yield in Glaciated British Columbia. Nature, 337, 452-454. https://doi.org/10.1038/337452a0

[40] Finné, M. (2014) Climate in the Eastern Mediterranean during the Holocene and beyond-A Peloponnesian Perspective. Doctoral Dissertation, Department of Physical Geography and Quaternary Geology, Stockholm University, Stockholm.

[41] Heymann, C., Nelle, O., Dorfler, W., Zagana, H., Nowaczyk, N., Xue, J. and Unkel, I. (2013) Late Glacial to mid-Holocene Palaeoclimate Development of Southern Greece Inferred from the Sediment Sequence of Lake Stymphalia (NE-Peloponnese). Quaternary International, 302, 42-60. https://doi.org/10.1016/j.quaint.2013.02.014

[42] Jin, Z., Wang, S., Shen, J., Zhang, E., Li, F., Ji, J. and Lu, X. (2001) Chemical Weathering since the Little Ice Age Recorded in Lake Sediments: A High-Resolution Proxy of Past Climate. Earth Surface Processes and Landforms, 26, 775-782. https://doi.org/10.1002/esp.224

[43] Jin, Z., Cao, J., Wu, J. and Wang, S. (2006a) A Rb/Sr Record of Catchment Weathering Response to Holocene Climate Change in Inner Mongolia. Earth Surface Processes and Landforms, 31, 285-291. https://doi.org/10.1002/esp.1243

[44] Dusar, B., Verstraeten, G., D’Haen, K., Bakker, J., Kaptijn, E. and Waelkens, M. (2012) Sensitivity of the Eastern Mediterranean Geomorphic System towards Environmental Change during the Late Holocene: A Chronological Perspective. Journal of Quaternary Science, 12, 371-382. https://doi.org/10.1002/jqs.1555 